\title{
Preharvest Applications of Sprayable 1-methylcyclopropene in the Orchard for Management of Apple Harvest and Postharvest Condition
}

\author{
Don C. Elfving ${ }^{1,5}$ \\ Washington State University, Tree Fruit Research and Extension Center, \\ 1100 N. Western Avenue, Wenatchee, WA 98801 \\ Stephen R. Drake ${ }^{2}$ \\ USDA/ARS, Tree Fruit Research Laboratory, Wenatchee, WA 98801
}

A. Nathan Reed
AgroFresh Inc., Spring House, PA 19477

Dwayne B. Visser ${ }^{4}$

Washington State University, Tree Fruit Research and Extension Center, Wenatchee, WA 98801

Additional index words. plant growth regulator, bioregulator, fruit maturity, ethylene, storage, Malus $\times$ domestica

\begin{abstract}
A sprayable formulation of 1-methylcyclopropene (1-MCP; AgroFresh, Spring House, PA) was applied to 'Scarletspur Delicious' and 'Cameo' apples in the orchard 1 to 3 weeks before harvest and compared in different postharvest studies with the commercial postharvest 1-MCP fruit treatment (SmartFresh; AgroFresh) and with aminoethoxyvinylglycine (AVG; ReTain; Valent BioSciences, Walnut Creek, CA). Treated apples were held in air storage for 50 to $60 \mathrm{~d}$ or in controlled-atmosphere storage for 120 to 125 or 215 to $225 \mathrm{~d}$. With increased concentration, sprayable 1-MCP treatments were effective at controlling flesh firmness loss and internal ethylene concentration (IEC) up to $225 \mathrm{~d}$ of storage as well as during a 7 -d poststorage shelf life simulation at room temperature. Application closer to harvest improved the effect of sprayable 1-MCP on control of flesh firmness loss and IEC. Concentrations of sprayable 1-MCP above $90 \mathrm{mg}$ a.i./L produced similar fruit effects to 1-MCP. Treatment with 1-MCP showed little effect on soluble solids concentration (SSC), titratable acidity (TA), or skin or flesh color in 'Delicious' but slightly increased SSC and TA in 'Cameo' apples. AVG applied 4 weeks before commercial harvest controlled IEC nearly as well as either sprayable 1-MCP or 1-MCP during storage, but AVG-treated fruit allowed to ripen for $7 \mathrm{~d}$ at room temperature after storage lost much more flesh firmness regardless of storage regime. Sprayable 1-MCP also reduced starch hydrolysis, IEC and fruit drop at harvest. Sprayable 1-MCP may offer new opportunities for effective preharvest management of apple fruit condition, storability, and poststorage fruit quality.
\end{abstract}

1-methylcyclopropene (1-MCP; SmartFresh; AgroFresh, Spring House, PA) is used widely in the apple industry to control postharvest ripening and quality loss of apples in storage (Fan et al., 1999; Watkins et al., 2000). The product is applied to apple fruit after harvest by fumigating the fruit in a

Received for publication 23 Feb. 2007. Accepted for publication 28 Mar. 2007.

We express appreciation to AgroFresh, Inc., Valent BioSciences, the Washington Tree Fruit Research Commission, and the Washington State University Agricultural Research Center for products, funds, and other support for these studies.

${ }^{1}$ Horticulturist and Professor.

${ }^{2}$ Research Horticulturist (retired).

${ }^{3}$ Manager, Postharvest Physiology.

${ }^{4}$ Agricultural Research Technologist III.

${ }^{5}$ To whom reprint requests should be addressed; e-mail delfving@wsu.edu to fruit quality maintenance after delayed harvest and after storage. For the past few years, AgroFresh, the company that manufactures and markets SmartFresh, the commercial form of 1-MCP for postharvest use on apples and other edible horticultural crops, has been developing a sprayable form of this product. A preliminary report by Yuan and Carbaugh (2007) suggested that the sprayable MCP material may have benefit for control of fruit quality loss when harvest is delayed but did not discuss effects on fruit during and after storage.

Aminoethoxyvinylglycine (AVG; ReTain; Valent BioSciences, Walnut Creek, CA), is another product registered for use before harvest on apples and other crops to delay fruit maturity and control preharvest drop (Byers, 1997; Greene, 2002). This product reduces fruit drop and delays fruit maturity by inhibiting the biosynthesis of ethylene in treated fruit tissues (Baker et al., 1978; Bangerth, 1978; Halder-Doll and Bangerth, 1987; Lieberman, 1979). The trials reported here describe results of applications of sprayable 1-MCP to 'Scarletspur Delicious' and 'Cameo' apple trees in the orchard and compare the effects of sprayable 1-MCP versus postharvest 1-MCP applications, as well as with preharvest treatment with AVG, on fruit quality after short- and long-term storage.

\section{Materials and Methods}

Three experiments were conducted between 2004 and 2005. All trials used randomized complete block designs with four single-tree replications per treatment. A proprietary formulation of 1-MCP ( $2 \%$ a.i. $)$ intended for application by spraying (sprayable 1-MCP; AgroFresh) was used in the trials, supplemented with a $1.0 \% \mathrm{v} / \mathrm{v}$ lowviscosity spray oil adjuvant supplied by AgroFresh. All applications were made with a hydraulic hand-gun sprayer (Nifty Nurserycart; Rear's Mfg. Co., Eugene, OR) to the point of runoff. AVG and 1-MCP concentrations are expressed in terms of the a.i.

Expt. 1: 'Scarletspur Delicious' (2004). Trees used in this study were 'Scarletspur Delicious'/MM.111 trees planted in East Wenatchee, WA, in 1979 at a spacing of $3.0 \times 6.1 \mathrm{~m}$. Application of AVG was made to a single-tree replicate in each block on 25 Aug. 2004. Trees were sprayed 4 weeks before first (commercial) harvest (WBFH) with $125 \mathrm{mg} \cdot \mathrm{L}^{-1}$ AVG supplemented with $0.05 \% \mathrm{v} / \mathrm{v}$ Sylgard 309 surfactant (WilburEllis, Fresno, CA). One single-tree replicate each in each of the four blocks was sprayed with sprayable $1-\mathrm{MCP}$ at either $125 \mathrm{mg} \cdot \mathrm{L}^{-1}$ or $250 \mathrm{mg} \cdot \mathrm{L}^{-1}$ on one of the following dates: 1 Sept. (3 WBFH), 8 Sept. (2 WBFH), or 15 Sept. (1 WBFH). Fruit from another singletree plot in each block received the standard $1-\mathrm{MCP}$ treatment in an enclosed chamber after harvest. Control trees were not sprayed with either bioregulator or oil (nine treatments in total). One 70-fruit sample was collected from each single-tree replicate in each 
block on 22 Sept. (commercial harvest) and again on 6 Oct. 2004. No phytotoxicity or other negative effects on the trees were observed.

Expt. 2: 'Scarletspur Delicious' (2005). Trees used in this study were from the same orchard used in 2004 but had not been used for any experimental purposes in 2004. Applications of sprayable 1-MCP were made to single-tree replicates in each block to runoff on either 13 Sept. (1 WBFH) or 20 Sept. (1 week before the second harvest date). On each spray date, two single-tree replicates each in each block were treated with sprayable1-MCP at $45 \mathrm{mg} \cdot \mathrm{L}^{-1}, 90 \mathrm{mg} \cdot \mathrm{L}^{-1}$, or 180 $\mathrm{mg} \cdot \mathrm{L}^{-1}$. Two additional single-tree replicates per block were not sprayed with either sprayable 1-MCP or spray oil. For each spray date, fruit from one of the two single-tree replicates in each block treated with each concentration of sprayable 1-MCP and fruit from one of the unsprayed single-tree replicates in each block were treated after fruit sample harvest with 1-MCP in an enclosed chamber. The other unsprayed tree in each block represented the control (eight treatments on each treatment date). A 70-fruit sample was collected on 20 Sept. (commercial harvest) from each replicate treated on 13 Sept. 2005. A separate 70-fruit sample was collected on 27 Sept. from each replicate treated on 20 Sept. 2005. No phytotoxicity or other negative effects on the trees were observed.

Expt. 3: 'Cameo' (2005). Trees used in this study were 'Cameo'/M.26 trees planted in Palisades, WA, in 1997 at a spacing of $2.4 \times 4.3 \mathrm{~m}$. Applications of sprayable 1-MCP were made to single-tree replicates in each block to runoff on either 19 Sept. (1 WBFH) or 26 Sept. (1 week before the second harvest date). The preharvest and postharvest treatments applied were the same as those described in Expt. 2 (eight treatments on each treatment date). A 70-fruit sample was collected on 26 Sept. (commercial harvest) from each replicate treated on 19 Sept. 2005. A separate 70-fruit sample was collected on 3 Oct. from each replicate treated on 26 Sept. 2005. No phytotoxicity or other negative effects on the trees were observed.

Apples were harvested on two dates each year corresponding to commercial harvest and commercial harvest plus either 1 or 2 weeks (Expt. 1: 22 Sept. and 6 Oct. 2004; Expt. 2: 20 Sept. and 27 Sept. 2005; Expt. 3: 26 Sept. and 3 Oct. 2005). After harvest, fruit samples designated for 1-MCP treatment were exposed to $1 \mathrm{mg} \cdot \mathrm{L}^{-1}$ of gaseous $\mathrm{MCP}$ for $24 \mathrm{~h}$ at $20^{\circ} \mathrm{C}$ in a sealed chamber with a circulation fan while the other fruit samples were maintained in cold storage. After exposure to $1-\mathrm{MCP}$, all stored fruit were placed in either air storage at $1{ }^{\circ} \mathrm{C}$ for 50 to $60 \mathrm{~d}$ or controlled-atmosphere (CA) storage [1.5\% $\mathrm{O}_{2}$ (oxygen) and $1.0 \% \mathrm{CO}_{2}$ (carbon dioxide) at $1{ }^{\circ} \mathrm{C}$ ] for 120 to 125 or 215 to $225 \mathrm{~d}$.

Fruit drop under each plot was counted weekly for 3 to 6 weeks starting with the first harvest date. Previously dropped fruit were raked from under test trees before applications and again after each weekly drop count.
Parameters of fruit quality [flesh firmness, skin color, flesh color, soluble solids content (SSC), titratable acidity (TA), starch index (SI), and internal ethylene concentration (IEC)] were determined on 10 fruit per replication within $6 \mathrm{~h}$ of harvest. After both air and CA storage, fruit quality was determined by evaluating 10 apples from each harvest date, treatment, and replication immediately after removal from storage; another group of 10 apples for each harvest date, treatment, and replication was evaluated to simulate shelf life after ripening for $7 \mathrm{~d}$ at room temperature.

Firmness was determined at two locations per apple with the Ta-XT2 Texture Analyzer (Texture Technologies, Scarsdale, NY) equipped with a $11.1-\mathrm{mm}$ probe. SSC and TA were determined from an aliquot of a composite expressed juice sample made from a cross-sectional slice from each of the same 10 fruit. Peel and flesh color were determined with the ColorFlex model 45/0 color spectrophotometer (Hunter Laboratories, Reston, VA) using the Hunter L*, a*, b* system and calculated hue angle $\left(\mathrm{h}^{\circ}\right)$ values (Hunter and Harold, 1987). An Abbé-type refractometer calibrated at $20{ }^{\circ} \mathrm{C}$ was used to determine SSC. TA was measured with a Radiometer titrator, model TTT85 (Radiometer, Copenhagen, Denmark). Acids were titrated to $\mathrm{pH}$ 8.2 with $0.1 \mathrm{~N}$ sodium hydroxide $(\mathrm{NaOH})$ and expressed as percent malic acid. Starch index was determined using a rating scale of 1 to 6 (Washington Apple Maturity Program, 1993). IEC was determined on five fruit for each replication, treatment, and storage period using a Hewlett-Packard model 5880A gas chromatograph (Ramsey, MN) with a flame ionization detector and equipped with Porapak Q column (Agilent, Palo Alto, CA). Fruit disorders (scald, watercore, internal browning, bitter pit, fruit rots) were visually assessed by laboratory personnel and expressed as the percentage of each fruit sample showing the disorder.

Analyses of variance or regression were used to assess the significant effects of treatments, relation, if any, of fruit behavior to product concentration and, when applicable, interactions. When harvest-date interactions with other factors were significant, separate harvest-date data are presented. All percentage values were transformed using the arcsine function before analysis. When appropriate, mean values were separated with the Waller-Duncan Bayesian k-ratio test $(P \leq 0.05)$ following a significant $\mathrm{F}$-test. Statistical analyses were performed using the General Linear Models procedure of the Statistical Analysis System program package (SAS Institute, Cary, NC).

\section{Results}

Expt. 1 (2004). There were almost no differences in fruit quality characteristics resulting from AVG or either of the 1-MCP treatments on the first harvest date (Table 1). The minor differences in fruit skin color in this very dark red cultivar were not horticulturally significant. Fruit were at an appropriate stage for long-term CA storage based on SI and IEC data. By the second harvest date 2 weeks later, small differences were present among treatments in all parameters except TA and skin color. There were significant differences in quality parameters from control only for SSC, which was lower for AVG and sprayable 1-MCP applied at either 2 or $1 \mathrm{WBFH}$. Although there were differences among treatments in flesh firmness, SI, and IEC, no treatment was significantly different from the control. Cumulative fruit drop over a 6week period after the first harvest date was retarded by AVG and by all sprayable 1-MCP treatments except $250 \mathrm{mg} \cdot \mathrm{L}^{-1}$ at $3 \mathrm{WBFH}$. Incidence of disorders was very low and did not differ among treatments (data not shown).

After $60 \mathrm{~d}$ in air storage, only the higher concentration of sprayable 1-MCP (250 $\mathrm{mg} \cdot \mathrm{L}^{-1}$ ) applied $1 \mathrm{WBFH}$ maintained greater flesh firmness in apples from the first harvest date evaluated immediately after removal (Table 2). IEC was strongly reduced compared with control, especially for the sprayable 1-MCP applications closer to harvest, the AVG treatment, and 1-MCP. Only sprayable 1-MCP applied $1 \mathrm{WBFH}$ and AVG showed IEC levels as low as the 1-MCP treatment. After $7 \mathrm{~d}$ at room temperature, control fruit had lost significant flesh firmness compared with 1-MCP and sprayable 1-MCP applied either 2 or 1 WBFH. Firmness in AVG-treated fruit was less than all sprayable 1-MCP applied either 2 or $1 \mathrm{WBFH}$ and 1-MCP. Fruit from the second harvest date showed a very similar pattern of response in terms of flesh firmness and IEC, although firmness values were lower and IEC levels higher than for fruit from the first harvest date. After $7 \mathrm{~d}$ at room temperature, control fruit no longer met the minimum firmness standard for shipping Washington 'Delicious' apples (less than $53.3 \mathrm{~N}$; Washington State Legislature, 1990). Although fruit treated with either sprayable $1-\mathrm{MCP}$ at 2 or 1 WBFH or AVG were firmer than controls, only the 1-MCP-treated fruit still maintained flesh firmness comparable to harvest values. There were no significant differences in SSC, $\mathrm{TA}$, or flesh color and no evidence of fruit disorders (data not shown).

After 125 or $225 \mathrm{~d}$ of CA storage, untreated fruit showed flesh firmness values close to or below the minimum firmness standard (Table 3; 125-day CA data not shown). The general pattern of fruit behavior was similar for both storage periods; fruit from the first harvest date showed higher flesh firmness values than control for all treatments, whereas IEC suppression was greater when sprayable 1-MCP applications were made closer to harvest. For the second harvest date, the closer sprayable 1-MCP was applied to harvest, the better the control over flesh firmness loss and IEC. AVG did not show as strong a controlling effect over flesh firmness loss as either sprayable 1-MCP or 1-MCP, which was as effective as sprayable 1-MCP. After $7 \mathrm{~d}$ at room temperature, control fruit from both harvest dates would not meet 


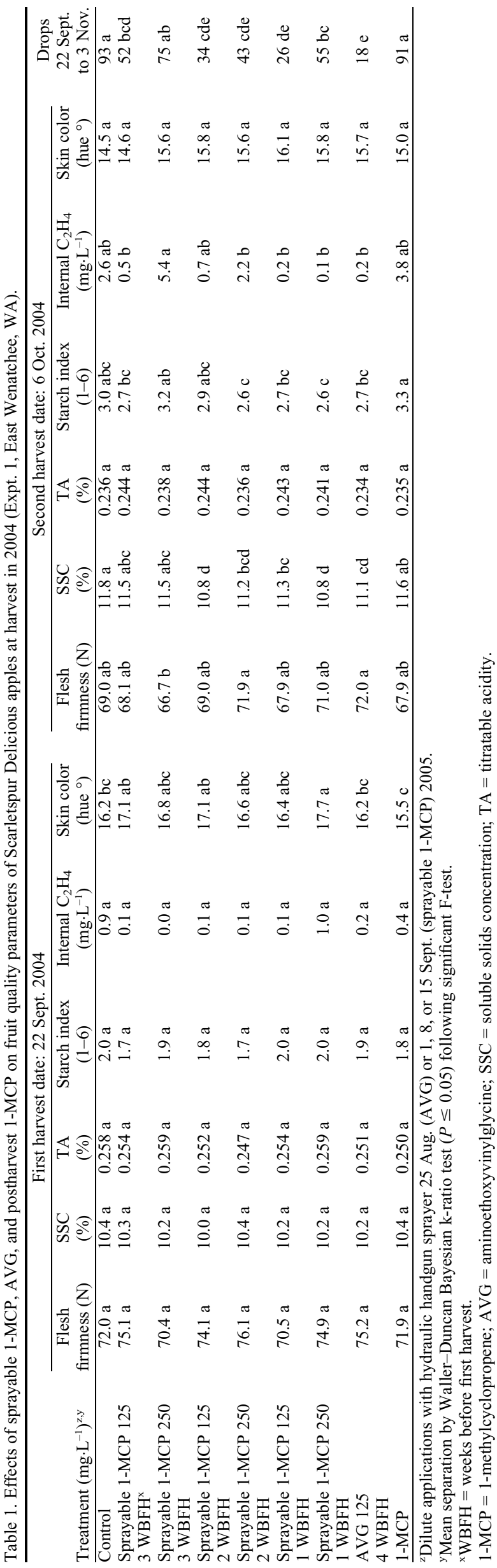

minimum firmness standards; the closer to harvest sprayable 1-MCP was applied, the better the retention of flesh firmness. Sprayable 1-MCP applied 1 WBFH was comparable to 1-MCP applied after harvest for control of IEC and reducing loss of flesh firmness. There were no significant differences in SSC, TA, flesh color, or evidence of fruit disorders after either storage period (data not shown).

Expt. 2 (2005). At harvest in 2005, sprayable 1-MCP had little effect on flesh firmness, SSC, TA, flesh color, or watercore incidence regardless of harvest date (Table 4). SI and IEC were reduced in inverse proportion to the concentration of sprayable 1-MCP, and red skin color was also reduced to a small extent by sprayable 1-MCP treatment, although the fruit were typically very dark red in color. Fruit drop was retarded by sprayable 1-MCP treatments. As expected, delaying both sprayable 1-MCP application and harvest by 1 week led to reduced flesh firmness, higher SSC, more starch hydrolysis, and less green fruit flesh, but no detectable changes in TA or IEC could be attributed to delaying treatment and harvest. There were no sprayable 1-MCP by harvest-date interactions. Watercore incidence was low and not related to treatments or harvest dates; incidence of other disorders was negligible and did not differ among treatments (data not shown).

After $50 \mathrm{~d}$ of air storage, all reported parameters showed a significant interaction between sprayable 1-MCP and 1-MCP treatments except for flesh firmness of firstharvest-date fruit evaluated immediately after removal from air storage (Table 5). In addition, all parameters showed significant harvest-date interactions. On the first harvest date, fruit flesh firmness showed no response either to sprayable 1-MCP concentration or to $1-\mathrm{MCP}$. In contrast, IEC was curvilinearly related to the concentration of sprayable 1-MCP for fruit not treated with 1-MCP. Fruit treated with 1-MCP showed no differences in flesh firmness or IEC regardless of sprayable 1-MCP treatment. After $7 \mathrm{~d}$ of simulated shelf life, flesh firmness of control fruit fell below the legal limit; the pattern of flesh firmness in response to sprayable 1-MCP and 1-MCP was similar to that shown by fruit immediately out of storage.

Fruit in air storage harvested on the second harvest date that did not receive a 1-MCP treatment showed a strongly curvilinear response for both flesh firmness and IEC to increasing concentrations of sprayable 1-MCP (Table 5). Fruit treated with 1-MCP showed no differences in flesh firmness or IEC regardless of sprayable 1-MCP treatment. There were no significant differences in SSC, TA, flesh color, or evidence of fruit disorders for either harvest date (data not shown).

Fruit examined after 120 or $215 \mathrm{~d}$ of CA storage showed a pattern of behavior and of interactions very similar to that described for fruit in air storage (Table 6; 120-d CA data not shown). The curvilinear response of flesh firmness and IEC to sprayable 1-MCP was 
Table 2. Effects of sprayable 1-MCP, AVG, and postharvest 1-MCP on fruit quality parameters of Scarletspur Delicious apples after $60 \mathrm{~d}$ air storage in 2004 (Expt. 1, East Wenatchee, WA).

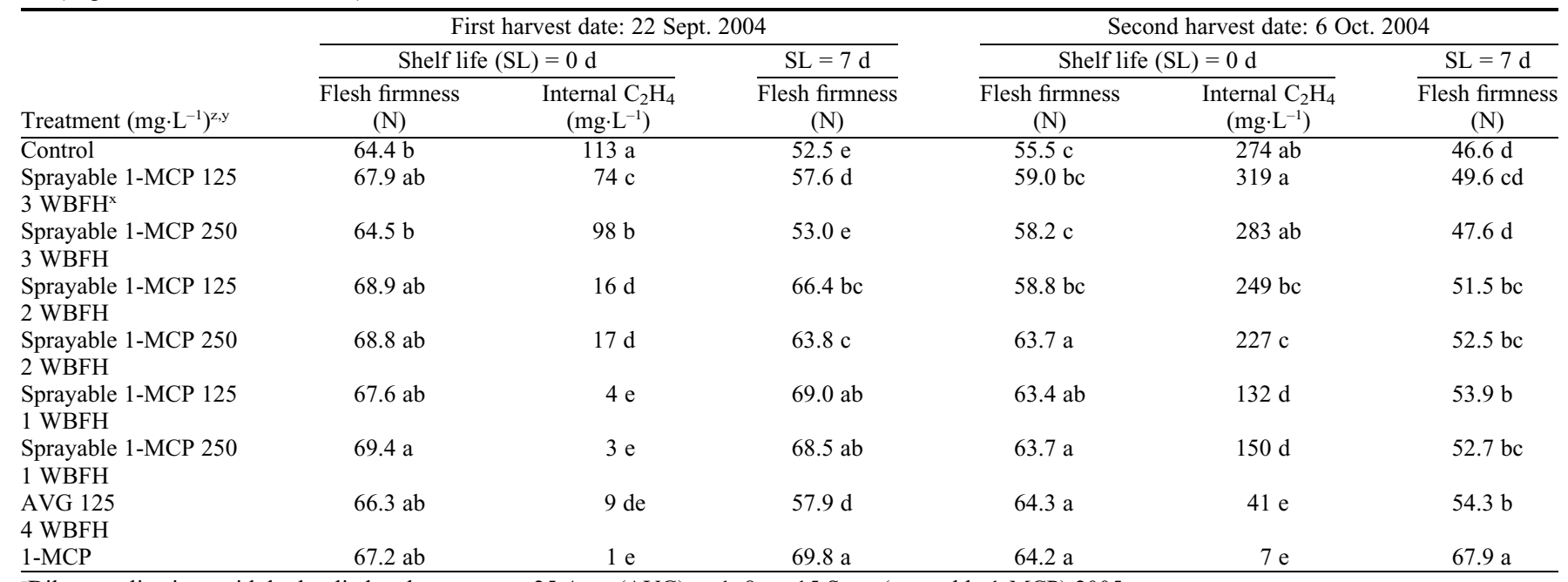

${ }^{2}$ Dilute applications with hydraulic handgun sprayer 25 Aug. (AVG) or 1, 8, or 15 Sept. (sprayable 1-MCP) 2005.

${ }^{\mathrm{y}}$ Mean separation by Waller-Duncan Bayesian k-ratio test $(P \leq 0.05)$ following significant $\mathrm{F}$ test.

${ }^{\mathrm{x}} \mathrm{WBFH}=$ weeks before first harvest.

$1-\mathrm{MCP}=1$-methylcyclopropene; AVG = aminoethoxyvinylglycine

Table 3. Effects of sprayable 1-MCP, AVG, and postharvest 1-MCP on fruit quality parameters of Scarletspur Delicious apples after $225 \mathrm{~d}$ CA storage in 2004 to 2005 (Expt. 1, East Wenatchee, WA).

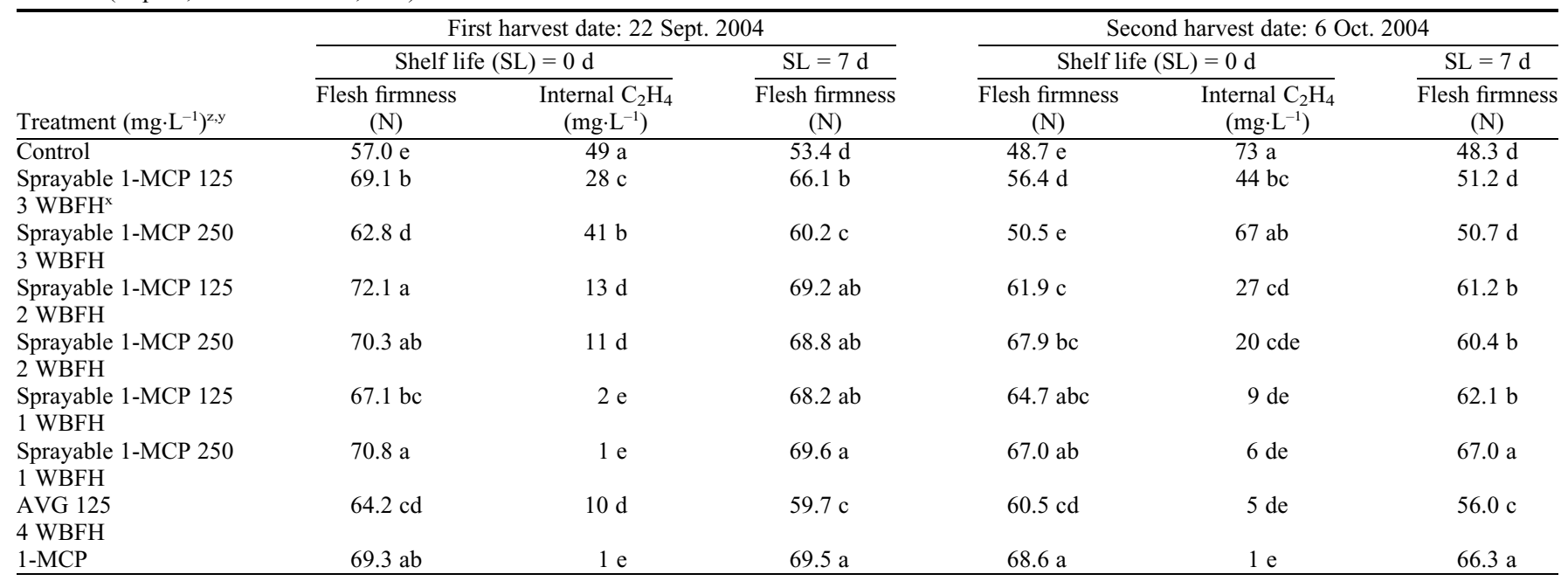

${ }^{2}$ Dilute applications with hydraulic handgun sprayer 25 Aug. (AVG) or 1, 8, or 15 Sept. (sprayable 1-MCP) 2005.

${ }^{\mathrm{y}}$ Mean separation by Waller-Duncan Bayesian k-ratio test $(P \leq 0.05)$ following significant $\mathrm{F}$ test.

${ }^{\mathrm{x}} \mathrm{WBFH}=$ weeks before first harvest.

$1-\mathrm{MCP}=1$-methylcyclopropene; $\mathrm{AVG}=$ aminoethoxyvinylglycine; $\mathrm{CA}=$ controlled-atmosphere.

Table 4. Effects of sprayable 1-MCP applied preharvest on fruit quality parameters of Scarletspur Delicious apples at harvest in 2005 (Expt. 2, East Wenatchee, WA).

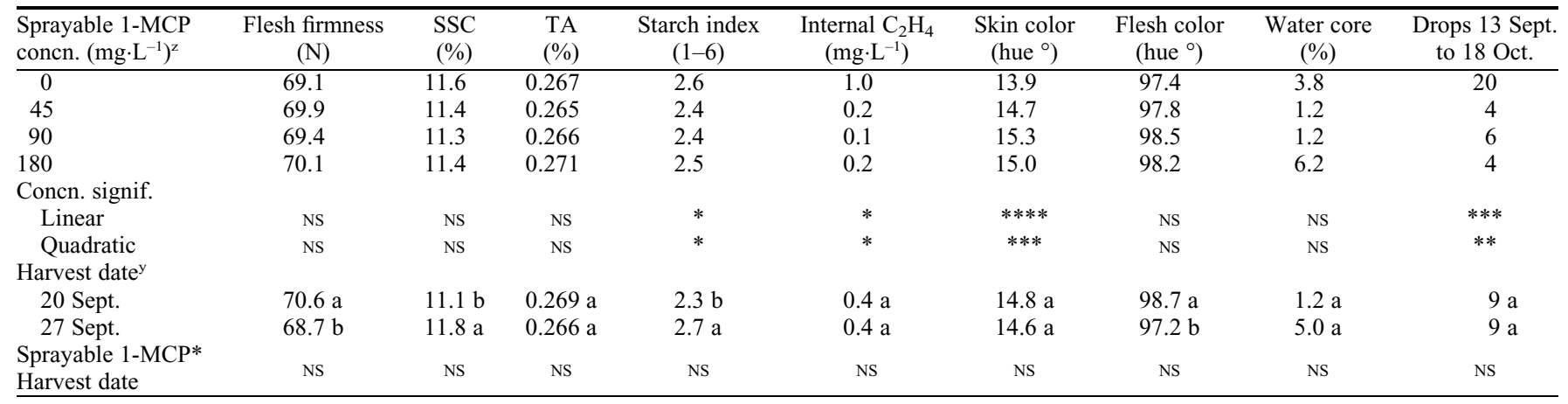

${ }^{2}$ Dilute applications with hydraulic handgun sprayer 13 Sept. or 20 Sept. 2005.

${ }^{\mathrm{y}}$ Mean separation by analysis of variance $(P \leq 0.05)$.

${ }_{\mathrm{Ns}, * * * * * * *, * * * * *}$ Nonsignificant or significant analysis of regression at $P \leq 0.05,0.01,0.001$, or 0.0001 , respectively.

$1-\mathrm{MCP}=1$-methylcyclopropene; $\mathrm{AVG}=$ aminoethoxyvinylglycine; $\mathrm{SSC}=$ soluble solids concentration; $\mathrm{TA}=$ titratable acidity. 
Table 5. Effects of sprayable 1-MCP applied preharvest and postharvest 1-MCP on fruit quality parameters of Scarletspur Delicious apples after $50 \mathrm{~d}$ air storage in 2005 (Expt. 2, East Wenatchee, WA).

\begin{tabular}{|c|c|c|c|c|c|c|c|c|c|c|c|}
\hline \multirow{4}{*}{$\begin{array}{l}\text { Sprayable } \\
1-\mathrm{MCP} \text { concn. } \\
\left(\mathrm{mg} \cdot \mathrm{L}^{-1}\right)^{\mathrm{z}}\end{array}$} & \multicolumn{5}{|c|}{ Harvest date: 20 Sept. 2005} & \multicolumn{6}{|c|}{ Harvest date: 27 Sept. 2005} \\
\hline & \multicolumn{3}{|c|}{ Shelf life $(\mathrm{SL})=0 \mathrm{~d}$} & \multirow{2}{*}{\multicolumn{2}{|c|}{$\begin{array}{c}\text { SL }=7 \mathrm{~d} \\
\text { Flesh firmness } \\
(\mathrm{N})\end{array}$}} & \multicolumn{4}{|c|}{ Shelf life $(\mathrm{SL})=0 \mathrm{~d}$} & \multirow{2}{*}{\multicolumn{2}{|c|}{$\begin{array}{c}\text { SL }=7 \mathrm{~d} \\
\text { Flesh firmness } \\
\text { (N) }\end{array}$}} \\
\hline & \multirow{2}{*}{$\begin{array}{l}\text { Flesh firmness } \\
\text { (N) }\end{array}$} & \multicolumn{2}{|c|}{$\begin{array}{l}\text { Internal } \mathrm{C}_{2} \mathrm{H}_{4} \\
\left(\mathrm{mg} \cdot \mathrm{L}^{-1}\right)\end{array}$} & & & \multicolumn{2}{|c|}{$\begin{array}{l}\text { Flesh firmness } \\
\text { (N) }\end{array}$} & \multicolumn{2}{|c|}{$\begin{array}{c}\text { Internal } \mathrm{C}_{2} \mathrm{H}_{4} \\
\left(\mathrm{mg} \cdot \mathrm{L}^{-1}\right)\end{array}$} & & \\
\hline & & $-1-\mathrm{MCP}$ & $\overline{+1-\mathrm{MCP}}$ & $-1-\mathrm{MCP}$ & $+1-\mathrm{MCP}$ & $-1-\mathrm{MCP}$ & $\overline{+1-\mathrm{MCP}}$ & $-1-\mathrm{MCP}$ & $+1-\mathrm{MCP}$ & $-1-\mathrm{MCP}$ & $+1-\mathrm{MCP}$ \\
\hline 0 & 68.5 & 65.6 & 2.0 & 53.3 & 67.9 & 60.6 & 66.2 & 115.4 & 5.2 & 51.2 & 67.5 \\
\hline 45 & 69.3 & 6.4 & 0.8 & 64.1 & 67.5 & 65.9 & 67.9 & 45.9 & 2.7 & 59.3 & 67.5 \\
\hline 90 & 68.2 & 2.4 & 0.4 & 63.8 & 66.9 & 65.4 & 65.7 & 6.6 & 1.1 & 63.1 & 67.3 \\
\hline 180 & 69.9 & 2.6 & 1.3 & 67.2 & 67.3 & 64.6 & 67.8 & 7.8 & 1.0 & 67.4 & 67.3 \\
\hline \multicolumn{12}{|l|}{ Concn. signif. } \\
\hline Linear & NS & $* * * *$ & NS & $* * *$ & NS & $* * *$ & NS & $* * * *$ & NS & $* * * *$ & NS \\
\hline Quadratic & NS & $* * * *$ & NS & $* *$ & NS & $* * *$ & NS & $* * * *$ & NS & $* *$ & NS \\
\hline \multicolumn{12}{|l|}{ 1-MCP } \\
\hline- & $68.6 \mathrm{a}$ & $19.2 \mathrm{a}$ & - & $62.1 \mathrm{~b}$ & - & $64.1 \mathrm{~b}$ & - & $43.9 \mathrm{a}$ & - & $60.3 \mathrm{~b}$ & - \\
\hline+ & $69.4 \mathrm{a}$ & - & $1.1 \mathrm{~b}$ & - & $67.4 \mathrm{a}$ & - & $66.9 \mathrm{a}$ & - & $2.5 \mathrm{~b}$ & - & $67.4 \mathrm{a}$ \\
\hline \multicolumn{12}{|l|}{ Sprayable 1-MCP } \\
\hline concn.* 1-MCP & NS & \multicolumn{2}{|c|}{$* * *$} & \multicolumn{2}{|c|}{$* * *$} & \multicolumn{2}{|c|}{$* *$} & \multicolumn{2}{|c|}{$* * * *$} & \multicolumn{2}{|c|}{$* * * *$} \\
\hline
\end{tabular}

${ }^{\mathrm{z}}$ Dilute applications with hydraulic handgun sprayer 13 Sept. or 20 Sept. 2005.

${ }^{\mathrm{y}}$ Mean separation by analysis of variance $(P \leq 0.05)$.

${ }_{\mathrm{Ns}, * * * * * * * * * * *}$ Nonsignificant or significant analysis of regression or variance at $P \leq 0.01,0.001$ or 0.0001 respectively.

$1-\mathrm{MCP}=1$-methylcyclopropene.

Table 6. Effects of sprayable 1-MCP applied preharvest and postharvest 1-MCP on fruit quality parameters of Scarletspur Delicious apples after $215 \mathrm{~d}$ CA storage in 2005 to 2006 (Expt. 2, East Wenatchee, WA).

\begin{tabular}{|c|c|c|c|c|c|c|c|c|c|c|c|c|}
\hline \multirow{3}{*}{$\begin{array}{l}\text { Sprayable } \\
1-\mathrm{MCP} \text { concn. } \\
\left(\mathrm{mg} \cdot \mathrm{L}^{-1}\right)^{\mathrm{z}}\end{array}$} & \multicolumn{6}{|c|}{ Harvest date: 20 Sept. 2005} & \multicolumn{6}{|c|}{ Harvest date: 27 Sept. 2005} \\
\hline & \multicolumn{4}{|c|}{ Shelf life $(\mathrm{SL})=0 \mathrm{~d}$} & \multirow{2}{*}{\multicolumn{2}{|c|}{$\begin{array}{c}\mathrm{SL}=7 \mathrm{~d} \\
\text { Flesh firmness } \\
(\mathrm{N})\end{array}$}} & \multicolumn{4}{|c|}{ Shelf life (SL) $=0 \mathrm{~d}$} & \multirow{2}{*}{\multicolumn{2}{|c|}{$\begin{array}{c}\text { SL }=7 \mathrm{~d} \\
\text { Flesh firmness } \\
(\mathrm{N})\end{array}$}} \\
\hline & \multicolumn{2}{|c|}{$\begin{array}{c}\text { Flesh firmness } \\
(\mathrm{N})\end{array}$} & \multicolumn{2}{|c|}{$\begin{array}{c}\text { Internal } \mathrm{C}_{2} \mathrm{H}_{4} \\
\left(\mathrm{mg} \cdot \mathrm{L}^{-1}\right) \\
\end{array}$} & & & \multicolumn{2}{|c|}{$\begin{array}{c}\text { Flesh firmness } \\
(\mathrm{N}) \\
\end{array}$} & \multicolumn{2}{|c|}{$\begin{array}{c}\text { Internal } \mathrm{C}_{2} \mathrm{H}_{4} \\
\left(\mathrm{mg} \cdot \mathrm{L}^{-1}\right) \\
\end{array}$} & & \\
\hline 0 & 57.8 & 68.8 & 8.9 & 0.1 & 51.9 & 70.3 & 59.2 & 69.0 & 12.5 & 0.3 & 48.2 & 66.6 \\
\hline 45 & 68.4 & 68.7 & 0.3 & 0.2 & 68.1 & 67.4 & 70.2 & 70.2 & 1.1 & 0.3 & 65.7 & 66.9 \\
\hline 90 & 66.6 & 66.9 & 0.4 & 0.3 & 68.0 & 69.5 & 70.7 & 70.3 & 0.4 & 0.2 & 66.1 & 67.0 \\
\hline 180 & 69.0 & 67.9 & 0.3 & 0.2 & 70.2 & 69.0 & 71.5 & 71.2 & 80.5 & 0.2 & 66.4 & 66.9 \\
\hline Linear & $* * * *$ & NS & $* * * *$ & NS & $* * * *$ & NS & $* * * *$ & NS & $* * * *$ & NS & $* * * *$ & NS \\
\hline Quadratic & $* * * *$ & NS & $* * *$ & NS & $* * * *$ & NS & $* * * *$ & NS & $* * *$ & NS & $* * * *$ & NS \\
\hline \multicolumn{13}{|l|}{$1-\mathrm{MCP}^{\mathrm{y}}$} \\
\hline- & $65.4 \mathrm{~b}$ & - & $2.5 \mathrm{a}$ & - & $64.5 \mathrm{~b}$ & - & $67.9 \mathrm{~b}$ & - & $3.6 \mathrm{a}$ & - & $61.6 \mathrm{~b}$ & - \\
\hline+ & - & $68.1 \mathrm{a}$ & - & $0.2 \mathrm{~b}$ & - & $69.0 \mathrm{a}$ & - & $70.4 \mathrm{a}$ & - & $0.2 \mathrm{~b}$ & - & $66.8 \mathrm{a}$ \\
\hline $\begin{array}{l}\text { Sprayable 1-MCP } \\
\text { concn.* } 1-\mathrm{MCP} \\
\end{array}$ & & & & & & & & * & & & & ** \\
\hline
\end{tabular}

${ }^{\mathrm{z}}$ Dilute applications with hydraulic handgun sprayer 13 Sept. or 20 Sept. 2005.

${ }^{\mathrm{y}}$ Mean separation by analysis of variance $(P \leq 0.05)$.

${ }_{\text {Ns, }, * * * * * * *}$ Nonsignificant or significant analysis of regression or variance at $P \leq 0.001$ or 0.0001 , respectively.

$1-\mathrm{MCP}=1$-methylcyclopropene; $\mathrm{CA}=$ controlled-atmosphere.

eliminated if fruit were also treated with $1-\mathrm{MCP}$, and concentrations of sprayable $1-\mathrm{MCP}$ at 45 or $90 \mathrm{mg} \cdot \mathrm{L}^{-1}$ or above produced fruit firmness and ethylene levels similar to those of fruit treated with 1-MCP. In general, fruit receiving sprayable 1-MCP, 1-MCP, or both treatments showed fairly comparable flesh firmness and IEC levels at both 0- and 7-d simulated shelf life for both harvest dates, values that compared quite well with similar values at harvest. Untreated control fruit were close to or below the mandated firmness limit at the time of removal from storage. There were no significant differences in SSC, TA, flesh color, or evidence of fruit disorders after either storage period (data not shown).

Expt. 3 (2005). Sprayable 1-MCP had little effect at harvest in 2005 on flesh firmness, SSC, TA, flesh color, or fruit drop in 'Cameo' apple (Table 7). Starch hydrolysis was reduced in proportion to the concentration of sprayable 1-MCP, and IEC on the second harvest date was similarly affected. Skin color showed a curvilinear response to sprayable 1-MCP treatment. Fruit drop was low and unaffected by any treatment. Delaying treatment and harvest by 1 week led to higher SSC, more starch hydrolysis, and slightly less green fruit flesh. Only IEC showed a sprayable 1-MCP by harvest-date interaction.

After $50 \mathrm{~d}$ of air storage, fruit not receiving 1-MCP showed a curvilinear relation to the concentration of sprayable 1-MCP for both flesh firmness and IEC for $0 \mathrm{~d}$ shelf life on both harvest dates (Tables 8 and 9). This behavior was completely eliminated if 1 MCP was applied. After $7 \mathrm{~d}$ of simulated shelf life, flesh firmness showed the same response to sprayable 1-MCP. In general, sprayable $1-\mathrm{MCP}$ treatment at $45 \mathrm{mg} \cdot \mathrm{L}^{-1}$ or greater resulted in levels of flesh firmness fairly comparable to those produced by 1 MCP both at the time when fruit were removed from storage and after $7 \mathrm{~d}$ at room temperature. However, even at the higher concentrations of sprayable 1-MCP, IEC was not reduced as much as by 1-MCP. SSC and TA were slightly increased by higher concentrations of sprayable 1-MCP for fruit harvested on the first harvest date, and TA levels were conserved in the presence of higher concentrations of sprayable 1-MCP or of 1-MCP on the second harvest date. Flesh color or evidence of fruit disorders after either storage period was unaffected by treatments (data not shown).

Fruit examined after 120 or $210 \mathrm{~d}$ of CA storage showed a pattern of behavior very similar to that described for fruit in air storage (Tables 10 and 11; 120-day CA data not shown). The curvilinear response to sprayable 1-MCP concentration of flesh firmness 
Table 7. Effects of sprayable 1-MCP applied preharvest on fruit quality parameters of Cameo apples at harvest in 2005 (Expt. 3, East Wenatchee, WA).

\begin{tabular}{|c|c|c|c|c|c|c|c|c|c|}
\hline \multirow[b]{2}{*}{$\begin{array}{l}\text { Sprayable 1-MCP } \\
\text { concn. }\left(\mathrm{mg} \cdot \mathrm{L}^{-1}\right)^{\mathrm{z}}\end{array}$} & \multirow[b]{2}{*}{$\begin{array}{l}\text { Flesh firmness } \\
(\mathrm{N})\end{array}$} & \multirow[b]{2}{*}{$\begin{array}{l}\text { SSC } \\
(\%)\end{array}$} & \multirow[b]{2}{*}{$\begin{array}{l}\text { TA } \\
(\%) \\
\end{array}$} & \multirow[b]{2}{*}{$\begin{array}{c}\text { Starch index } \\
(1-6)\end{array}$} & \multicolumn{2}{|c|}{ Internal $\mathrm{C}_{2} \mathrm{H}_{4}\left(\mathrm{mg} \cdot \mathrm{L}^{-1}\right)$} & \multirow[b]{2}{*}{$\begin{array}{c}\text { Skin color } \\
\left.\text { (hue }^{\circ}\right)\end{array}$} & \multirow[b]{2}{*}{$\begin{array}{l}\text { Flesh color } \\
\text { (hue }^{\circ} \text { ) }\end{array}$} & \multirow[b]{2}{*}{$\begin{array}{c}\text { Drops } 26 \text { Sept. to } \\
17 \text { Oct. }\end{array}$} \\
\hline & & & & & $\begin{array}{l}\text { Harvest } \\
\text { 26 Sept. }\end{array}$ & $\begin{array}{l}\text { Harvest } \\
3 \text { Oct. }\end{array}$ & & & \\
\hline 0 & 64.9 & 13.2 & 0.458 & 3.4 & 0.1 & 0.9 & 43.1 & 95.2 & 5 \\
\hline 180 & 65.0 & 13.0 & 0.476 & 3.1 & 0.1 & 0.2 & 43.1 & 95.3 & 6 \\
\hline \multicolumn{10}{|l|}{ Concn. signif. } \\
\hline \multicolumn{10}{|l|}{ Harvest Date ${ }^{y}$} \\
\hline 26 Sept. & $64.9 \mathrm{a}$ & $12.7 \mathrm{~b}$ & $0.477 \mathrm{a}$ & $3.0 \mathrm{~b}$ & $0.1 \mathrm{~b}$ & - & $47.4 \mathrm{a}$ & $95.9 \mathrm{a}$ & $5 \mathrm{a}$ \\
\hline 3 Oct. & $65.4 \mathrm{a}$ & $13.2 \mathrm{a}$ & 0.469 a & $3.4 \mathrm{a}$ & - & $0.4 \mathrm{a}$ & $44.6 \mathrm{a}$ & $95.0 \mathrm{~b}$ & $5 \mathrm{a}$ \\
\hline $\begin{array}{l}\text { Sprayable 1-MCP* } \\
\text { Harvest date }\end{array}$ & NS & NS & NS & NS & & & NS & NS & NS \\
\hline
\end{tabular}

${ }^{2}$ Dilute applications with hydraulic handgun sprayer 19 Sept. or 26 Sept. 2005.

${ }^{\mathrm{y}}$ Mean separation by analysis of variance $(P \leq 0.05)$.

${ }_{\text {Ns, }}{ }^{*}$ Nonsignificant or significant analysis of regression or variance at $P \leq 0.05$.

1 -MCP $=1$-methylcyclopropene; $\mathrm{SSC}=$ soluble solids concentration; $\mathrm{TA}=$ titratable acidity .

Table 8. Effects of sprayable 1-MCP applied preharvest and postharvest 1-MCP on fruit quality parameters of Cameo apples after $50 \mathrm{~d}$ air storage in 2005 to 2006 [harvest 1 (26 Sept. 2005)].

\begin{tabular}{|c|c|c|c|c|c|c|c|c|c|c|}
\hline \multirow{3}{*}{$\begin{array}{l}\text { Sprayable 1-MCP } \\
\text { concn. }\left(\mathrm{mg} \cdot \mathrm{L}^{-1}\right)^{\mathrm{z}}\end{array}$} & \multicolumn{6}{|c|}{ Shelf life $(\mathrm{SL})=0 \mathrm{~d}$} & \multicolumn{4}{|c|}{$\mathrm{SL}=7 \mathrm{~d}$} \\
\hline & \multicolumn{2}{|c|}{ Flesh firmness $(\mathrm{N})$} & \multirow[b]{2}{*}{$\operatorname{SSC}(\%)$} & \multirow[b]{2}{*}{ TA $(\%)$} & \multicolumn{2}{|c|}{ Internal $\mathrm{C}_{2} \mathrm{H}_{4}\left(\mathrm{mg} \cdot \mathrm{L}^{-1}\right)$} & \multicolumn{2}{|c|}{ Flesh firmness $(\mathrm{N})$} & \multirow[b]{2}{*}{ SSC $(\%)$} & \multirow[b]{2}{*}{ TA $(\%)$} \\
\hline & $-1-\mathrm{MCP}$ & $+1-\mathrm{MCP}$ & & & $-1-\mathrm{MCP}$ & $+1-\mathrm{MCP}$ & -1-MCP & $+1-\mathrm{MCP}$ & & \\
\hline 0 & 62.4 & 65.8 & 13.6 & 0.417 & 48.8 & 4.6 & 54.3 & 62.7 & 13.9 & 0.406 \\
\hline 45 & 64.3 & 66.5 & 13.8 & 0.441 & 19.7 & 1.3 & 63.0 & 65.2 & 13.8 & 0.429 \\
\hline 90 & 65.6 & 67.0 & 14.1 & 0.442 & 3.2 & 0.7 & 63.8 & 65.2 & 14.2 & 0.436 \\
\hline 180 & 67.0 & 64.1 & 14.0 & 0.451 & 2.1 & 0.8 & 64.5 & 63.8 & 14.3 & 0.449 \\
\hline \multicolumn{11}{|l|}{ Concn. signif. } \\
\hline Linear & $* * *$ & NS & $*$ & $*$ & $* * * *$ & NS & $* * *$ & NS & $*$ & * \\
\hline Quadratic & NS & NS & $*$ & NS & $* * * *$ & NS & $* *$ & NS & NS & NS \\
\hline \multicolumn{11}{|l|}{$1-\mathrm{MCP}^{\mathrm{y}}$} \\
\hline- & $65.0 \mathrm{a}$ & - & $13.9 \mathrm{a}$ & $0.440 \mathrm{a}$ & $18.4 \mathrm{a}$ & - & $61.4 \mathrm{~b}$ & - & $14.1 \mathrm{a}$ & $0.428 \mathrm{a}$ \\
\hline+ & - & $66.9 \mathrm{a}$ & $13.8 \mathrm{a}$ & $0.435 \mathrm{a}$ & - & $1.8 \mathrm{~b}$ & - & $64.2 \mathrm{a}$ & $14.0 \mathrm{a}$ & $0.432 \mathrm{a}$ \\
\hline \multicolumn{11}{|l|}{ Sprayable 1-MCP } \\
\hline concn. ${ }^{*} 1-\mathrm{MCP}$ & & & NS & NS & & & & & NS & NS \\
\hline
\end{tabular}

${ }^{2}$ Dilute applications with hydraulic handgun sprayer 19 Sept. 2005.

${ }^{\mathrm{y}}$ Mean separation by analysis of variance $(P \leq 0.05)$.

${ }_{\mathrm{Ns}, *, * * * * * *, * * * *}$ Nonsignificant or significant analysis of regression or variance at $P \leq 0.05,0.01,0.001$, or 0.0001 , respectively.

$1-\mathrm{MCP}=1$-methylcyclopropene; $\mathrm{SSC}=$ soluble solids concentration; TA = titratable acidity.

Table 9. Effects of sprayable 1-MCP applied preharvest and postharvest 1-MCP on fruit quality parameters of Cameo apples after $50 \mathrm{~d}$ air storage in 2005 to 2006 [harvest 2 (3 Oct. 2005)].

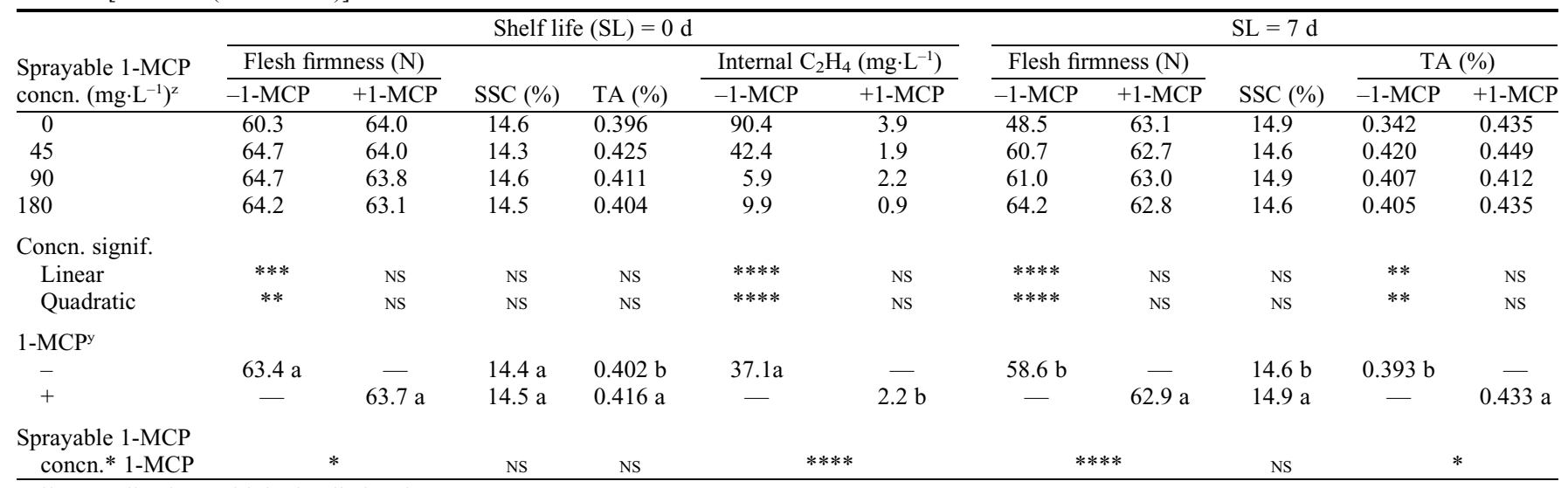

${ }^{\mathrm{z}}$ Dilute applications with hydraulic handgun sprayer 26 Sept. 2005.

${ }^{\mathrm{y}}$ Mean separation by analysis of variance $(P \leq 0.05)$.

${ }_{\mathrm{Ns}, * * * * * * *, * * * *}$ Nonsignificant or significant analysis of regression or variance at $P \leq 0.05,0.01,0.001$, or 0.0001 , respectively.

$1-\mathrm{MCP}=1$-methylcyclopropene; $\mathrm{SSC}=$ soluble solids concentration; TA = titratable acidity.

and IEC was eliminated if fruit were also treated with 1-MCP. SSC increased slightly in relation to sprayable 1-MCP concentration on the first harvest date, but after $7 \mathrm{~d}$ ripening, those differences had disappeared. TA levels suggested some conservation of acidity after $7 \mathrm{~d}$ of ripening associated with higher concentrations of sprayable 1-MCP for fruit harvested on the second harvest date. Flesh color and evidence of fruit disorders after either storage period were unaffected by treatments (data not shown). 
Table 10. Effects of sprayable 1-MCP applied preharvest and postharvest 1-MCP on fruit quality parameters of Cameo apples after $210 \mathrm{~d}$ CA storage in 2005 to 2006 [harvest 1 (26 Sept. 2005)].

\begin{tabular}{|c|c|c|c|c|c|c|c|c|c|c|}
\hline \multirow{3}{*}{$\begin{array}{l}\text { Sprayable 1-MCP } \\
\text { concn. }\left(\mathrm{mg} \cdot \mathrm{L}^{-1}\right)^{\mathrm{z}}\end{array}$} & \multicolumn{6}{|c|}{ Shelf life $(\mathrm{SL})=0 \mathrm{~d}$} & \multicolumn{4}{|c|}{$\mathrm{SL}=7 \mathrm{~d}$} \\
\hline & \multicolumn{2}{|c|}{ Flesh firmness $(\mathrm{N})$} & \multirow[b]{2}{*}{$\operatorname{SSC}(\%)$} & \multirow[b]{2}{*}{ TA $(\%)$} & \multicolumn{2}{|c|}{ Internal $\mathrm{C}_{2} \mathrm{H}_{4}\left(\mathrm{mg} \cdot \mathrm{L}^{-1}\right)$} & \multicolumn{2}{|c|}{ Flesh firmness $(\mathrm{N})$} & \multirow[b]{2}{*}{$\operatorname{SSC}(\%)$} & \multirow[b]{2}{*}{ TA $(\%)$} \\
\hline & $-1-\mathrm{MCP}$ & $+1-\mathrm{MCP}$ & & & $-1-\mathrm{MCP}$ & $+1-\mathrm{MCP}$ & -1-MCP & $+1-\mathrm{MCP}$ & & \\
\hline 0 & 58.9 & 69.1 & 14.1 & 0.369 & 32.4 & 0.1 & 54.5 & 65.8 & 14.0 & 0.353 \\
\hline 45 & 66.0 & 67.3 & 14.7 & 0.384 & 1.6 & 0.2 & 63.8 & 66.1 & 14.2 & 0.373 \\
\hline 90 & 67.5 & 69.0 & 14.5 & 0.388 & 2.2 & 0.1 & 65.6 & 65.6 & 14.3 & 0.375 \\
\hline 180 & 69.6 & 68.7 & 14.8 & 0.397 & 3.9 & 0.2 & 67.6 & 65.8 & 14.6 & 0.376 \\
\hline \multicolumn{11}{|l|}{ Concn. signif. } \\
\hline Linear & $* * *$ & NS & $*$ & NS & $* * * *$ & NS & $* * * *$ & NS & NS & NS \\
\hline Quadratic & $*$ & NS & NS & NS & $* * * *$ & NS & $* * *$ & NS & NS & NS \\
\hline \multicolumn{11}{|l|}{ 1-MCPy } \\
\hline- & $65.5 \mathrm{~b}$ & - & $14.6 \mathrm{a}$ & $0.373 \mathrm{a}$ & $10.0 \mathrm{a}$ & - & $62.9 \mathrm{~b}$ & - & $14.2 \mathrm{a}$ & $0.367 \mathrm{a}$ \\
\hline+ & - & $68.5 \mathrm{a}$ & $14.5 \mathrm{a}$ & $0.396 \mathrm{a}$ & - & $0.2 \mathrm{~b}$ & - & $65.8 \mathrm{a}$ & $14.3 \mathrm{a}$ & $0.371 \mathrm{a}$ \\
\hline Sprayable 1-MCP & & & NS & NS & & & & & Ne & SC, \\
\hline
\end{tabular}

zDilute applications with hydraulic handgun sprayer 19 Sept. 2005.

${ }^{\mathrm{y}}$ Mean separation by analysis of variance $(P \leq 0.05)$.

${ }_{\text {Ns, }{ }^{*}, * * * * * * * * * *}$ Nonsignificant or significant analysis of regression or variance at $P \leq 0.05,0.01,0.001$, or 0.0001 , respectively.

$1-\mathrm{MCP}=1$-methylcyclopropene; $\mathrm{SSC}=$ soluble solids concentration; $\mathrm{TA}=$ titratable acidity.

Table 11. Effects of sprayable 1-MCP applied preharvest and postharvest 1-MCP on fruit quality parameters of Cameo apples after $210 \mathrm{~d}$ CA storage in 2005 to 2006 [harvest 2 (3 Oct. 2005)].

\begin{tabular}{|c|c|c|c|c|c|c|c|c|c|c|}
\hline \multirow{2}{*}{$\begin{array}{l}\text { Sprayable 1-MCP } \\
\text { concn. }\left(\mathrm{mg} \cdot \mathrm{L}^{-1}\right)^{\mathrm{z}}\end{array}$} & \multicolumn{6}{|c|}{ Shelf life $(S L)=0 \mathrm{~d}$} & \multicolumn{4}{|c|}{$\mathrm{SL}=7 \mathrm{~d}$} \\
\hline & \multicolumn{2}{|c|}{ Flesh firmness $(\mathrm{N})$} & $\mathrm{SSC}(\%)$ & TA $(\%)$ & \multicolumn{2}{|c|}{ Internal $\mathrm{C}_{2} \mathrm{H}_{4}\left(\mathrm{mg} \cdot \mathrm{L}^{-1}\right)$} & \multicolumn{2}{|c|}{ Flesh firmness $(\mathrm{N})$} & $\mathrm{SSC}(\%)$ & TA $(\%)$ \\
\hline 0 & 54.4 & 63.5 & 14.6 & 0.381 & 32.4 & 0.5 & 59.1 & 66.0 & 14.5 & 0.343 \\
\hline 90 & 64.5 & 63.2 & 14.7 & 0.393 & 1.1 & 0.6 & 69.9 & 66.5 & 14.4 & 0.367 \\
\hline 180 & 63.2 & 62.6 & 14.6 & 0.379 & 0.4 & 0.6 & 69.0 & 68.4 & 14.4 & 0.352 \\
\hline \multicolumn{11}{|l|}{ Concn. signif. } \\
\hline \multicolumn{11}{|l|}{$1-\mathrm{MCP}^{\mathrm{y}}$} \\
\hline- & $61.2 \mathrm{~b}$ & - & $14.6 \mathrm{a}$ & $0.376 \mathrm{~b}$ & $9.5 \mathrm{a}$ & - & $67.0 \mathrm{a}$ & - & $14.3 \mathrm{a}$ & $0.344 \mathrm{~b}$ \\
\hline+ & - & $62.7 \mathrm{a}$ & $14.7 \mathrm{a}$ & $0.403 \mathrm{a}$ & - & $0.7 \mathrm{~b}$ & - & $67.1 \mathrm{a}$ & $14.4 \mathrm{a}$ & $0.369 \mathrm{a}$ \\
\hline
\end{tabular}

Sprayable 1-MCP

concn.* 1-MCP

$* * * *$

NS

$* * * *$

NS

NS

${ }^{\mathrm{z} D i l u t e}$ applications with hydraulic handgun sprayer 26 Sept. 2005.

${ }^{\mathrm{y}}$ Mean separation by analysis of variance $(P \leq 0.05)$.

Ns,*,**,***,***** Nonsignificant or significant analysis of regression or variance at $P \leq 0.05,0.01,0.001$, or 0.0001 , respectively.

$1-\mathrm{MCP}=1$-methylcyclopropene; $\mathrm{SSC}=$ soluble solids concentration; $\mathrm{TA}=$ titratable acidity.

\section{Discussion}

In general, sprayable 1-MCP applications in the orchard within a few weeks before harvest produced fruit responses for both cultivars and from all storage regimes that were similar to, but not identical to, effects of 1-MCP treatment after harvest. The parameters most consistently affected by both sprayable 1-MCP and 1-MCP applications were flesh firmness and IEC. In these studies, fruit held in storage up to $225 \mathrm{~d}$ still showed strong effects on flesh firmness and IEC from either sprayable 1-MCP or 1-MCP treatment. Occasional small differences in SSC, TA, and skin or flesh color were observed, but in no trial was there a consistent pattern of treatmentrelated effects on those parameters throughout the various storage regimes. In 2004, better control of flesh firmness loss and IEC was obtained from sprayable 1-MCP applied closer to harvest. In 2005, lower spray concentrations of sprayable 1-MCP proved nearly as or as effective when applied 1 week before harvest as the higher concentrations applied 2 or 3 WBFH in 2004. These observations suggest that the receptors for ethylene that are treated by a postharvest fumigation with 1-MCP gas are present, active, and capable of interacting with 1-MCP before harvest. The evidence presented here suggests that the closer to harvest the sprayable 1-MCP treatments are made, the more similar its effects are to a postharvest application. Sprayable 1-MCP a.i. concentrations in these trials were much higher than the concentration used by Byers et al. (2005), which produced only minor effects on fruit.

On removal from storage in 2004, fruit treated with AVG $4 \mathrm{WBFH}$ tended to maintain flesh firmness and IEC values close to or equivalent to levels produced by the 1-MCP treatment and sprayable 1-MCP applications at $1 \mathrm{WBFH}$. However, over $7 \mathrm{~d}$ at room temperature, AVG-treated fruit from all storage regimes lost much more firmness than did fruit from those same MCP treatments. No ethylene measurements were made on fruit after the shelf life simulation began. If AVG did not control ethylene biosynthesis during the poststorage shelf life period, those fruit would have softened more rapidly as a result of the presence of active ethylene receptor sites in the fruit. The absence of significant softening of 1-MCP treated fruit after $7 \mathrm{~d}$ at room temperature may have been the result of continued control over ethylene biosynthesis, continued control over ethylene perception, or a combination of both factors.

Preharvest 1-MCP applications produced strong effects on delay in starch hydrolysis before harvest, suppression of ethylene formation in the fruit, conservation of flesh firmness during and after storage, possible beneficial effects on fruit acid levels, and minimal effects on SSC and fruit color development. These results suggest that 1MCP applied before harvest may also permit delaying commercial harvest while preserving the fruit quality and storability attributes of optimally matured fruit. If so, this benefit might aid in more effective management of limited harvest-labor resources. Although much more information is still needed, the ability to apply 1-MCP before harvest may 
provide multiple benefits for the apple grower and marketer.

\section{Literature Cited}

Baker, J.E., M. Lieberman, and J.D. Anderson. 1978. Inhibition of ethylene production in fruit slices by a rhizobitoxine analog and free radical scavengers. Plant Physiol. 61:886-888.

Bangerth, F. 1978. The effect of a substituted amino acid on ethylene biosynthesis, respiration, ripening and preharvest drop of apple fruits. J. Amer. Soc. Hort. Sci. 103:401-404.

Binder, B.M. and A.B. Bleecker. 2003. A model for ethylene receptor function and 1-methylcyclopropene action. Acta Hort. 628:177-187.

Blankenship, S.M. and J.M. Dole. 2003. 1-methylcyclopropene: A review. Postharvest Biol. Technol. 28:1-25.

Byers, R.E. 1997. Effects of aminoethoxyvinylglycine (AVG) on preharvest drop, maturity, and cracking of several apple cultivars. J. Tree Fruit Prod. 2:77-97.

Byers, R.E., D.H. Carbaugh, and L.D. Combs. 2005. Ethylene inhibitors delay fruit drop, maturity, and increase fruit size of 'Arlet' apples. HortScience 40:2061-2065.

DeEll, J.R., J.T. Ayres, and D.P. Murr. 2006. 1methylcyclopropene influences 'Empire' and 'Delicious' apple quality during long-term commercial storage. HortTechnology 17:46-51.

DeEll, J.R., D.P. Murr, M.D. Porteous, and H.V.P Rupasinghe. 2002. Influence of temperature and duration of 1-methylcyclopropene (1-MCP) treatment on apple quality. Postharvest Biol. Technol. 24:349-353.

DeLong, J.M., R.K. Prange, and P.A. Harrison. 2004. The influence of 1-methylcyclopropene on 'Cortland' and 'McIntosh' apple quality following long-term storage. HortScience 39:1062-1065.

Fan, X.T., S.M. Blankenship, and J.P. Mattheis 1999. 1-methylcyclopropene inhibits apple ripening. J. Amer. Soc. Hort. Sci. 124:690-695.

Fan, X.T. and J.P. Mattheis. 1999a. Impact of 1methylcyclopropene and methyl jasmonate on apple volatile production. J. Agr. Food Chem. 47:2847-2853.

Fan, X.T. and J.P. Mattheis. 1999b. Development of apple superficial scald, soft scald, core flush, and greasiness is reduced by MCP. J. Agr. Food Chem. 47:3063-3068.

Greene, D.W. 2002. Preharvest drop control and maturity of 'Delicious' apples as affected by aminoethoxyvinylglycine (AVG). J. Tree Fruit Prod. 3:1-10.

Halder-Doll, H. and F. Bangerth. 1987. Inhibition of autocatalytic $\mathrm{C}_{2} \mathrm{H}_{4}$-biosynthesis by AVG applications and consequences on the physiological behaviour and quality of apple fruits in cool storage. Scientia Hort. 33:87-96.

Hunter, R.S. and R.W. Harold. 1987. The measurement of appearance. 2nd ed. Wiley, New York.

Lieberman, M. 1979. Biosynthesis and action of ethylene. Annu. Rev. Plant Physiol. 30:533591.

Lurie, S., C. Pre-Aymard, U. Ravid, O. Larkov, and E. Fallik. 2002. Effect of 1-methylcyclopropene on volatile emission and aroma in cv. Anna apples. J. Agr. Food Chem. 50:4251-4256.

Prange, R.K. and J.M. DeLong. 2003. 1-Methylcyclopropene: The 'magic bullet' for horticultural products? Chron. Horticult. 43:11-14.

Sisler, E.C. and M. Serek. 1997. Inhibitors of ethylene responses in plants at the receptor level: Recent developments. Physiol. Plant. 100:577-582.

Sisler, E.C. and M. Serek. 2003. Compounds interacting with the ethylene receptor in plants. Plant Biol. 5:473-480.

Washington Apple Maturity Program. 1993. Washington apple maturity handbook. Washington Apple Maturity Program, Wenatchee.

Washington State Legislature. 1990. Washington inspection procedures. Washington Agricultural Code (WAC) 16-403-142, 15 Jan. 1990. Washington State Legislature, Olympia, WA.

Watkins, C.B. 2006. The use of 1-methylcyclopropene (1-MCP) on fruits and vegetables. Biotechnol. Adv. 24:389-409.

Watkins, C.B., J.F. Nock, and B.D. Whitaker 2000. Responses of early, mid and late season apple cultivars to postharvest application of 1-methylcyclopropene (1-MCP) under air and controlled atmosphere conditions. Postharvest Biol. Technol. 19:17-32.

Yuan, R.C. and D.H. Carbaugh. 2007. Effects of NAA, AVG and 1-MCP on ethylene biosynthesis, preharvest fruit drop, fruit maturity, and quality of 'Golden Supreme' and 'Golden Delicious' apples. HortScience 42:101-105. 